\title{
KAJIAN PERATURAN GUBERNUR JAWA BARAT TENTANG PENGGUNAAN BATIK TRADISIONAL DAN UPAYA PENCAPAIAN INDIKASI GEOGRAFIS
}

\author{
Saftiyaningsih Ken Atik, Mochamad Djalu Djatmiko \\ (Email: kenatik25@gmail.com) \\ Kriya Tekstil dan Fashion \\ Fakultas Sosial Humaniora \\ Universitas Muhammadiyah Bandung \\ Jl. Soekarno Hatta No. 752 Bandung-40614, Jawa Barat, Indonesia \\ Desain Produk \\ Institut Teknologi Nasional \\ Fakultas Arsitektur dan Desain \\ JI. PKH. Mustopha No.23, Bandung 40124, Jawa Barat, Indonesia
}

\begin{abstract}
ABSTRAK
Potensi kekuatan kerajinan batik tradisional Jawa Barat telah tumbuh dan berkembang di 27 kabupaten/kota yang tersebar dari belahan timur Kabupaten Cirebon hingga di ujung sebelah barat Jawa Barat yaitu Kotamadya Depok. Keragaman corak dan ragam hias batik tradisional Jawa Barat merupakan sumber kekuatan yang tidak dimiliki oleh provinsi lainnya. Penelitian ini menggunakan metode pendekatan yuridis empiris atau pendekatan perundang-undangan untuk mengenal peraturan-peraturan yang sudah berjalan di masyarakat serta spesifikasi penelitian deskriptif analitis menggunakan data primer dan data sekunder. Keunggulan batik Jawa Barat sudah terbukti telah mewarnai khazanah kekayaan batik Indonesia bersama batik tradisional lainnya. Dukungan pemerintah, dalam hal ini Gubernur Provinsi Jawa Barat, melalui Peraturan dan Keputusan Gubernur diharapkan dapat meningkatkan produktivitas dan kejayaan batik tradisional Jawa Barat yang berkaitan dengan potensi ekonomi dan sebagai bentuk dukungan Pemda Jabar dalam Program Pemajuan Kebudayaan Daerah yang telah ditetapkan di dalam Undang-Undang No. 5 tahun 2007. Penelitian ini diharapkan melahirkan keputusan Gubernur Jawa Barat tentang penggunaan produk batik tradisional (batik asli) dan ragam hias khas batik Jawa Barat merupakan sebuah tindakan strategis dalam upaya melestarikan, mengembangkan, dan melindungi indikasi geografis batik tradisional yang pada akhirnya dapat meningkatkan kesejahteraan masyarakat Jawa Barat pada umumnya.
\end{abstract}

Kata kunci: : batik Jawa Barat; indikasi geografis; tindakan strategis

\begin{abstract}
The potential strength of traditional West Java batik crafts has grown and developed in 27 regencies/cities spread from the eastern part of the Cirebon district to the western end of West Java, Depok Municipality. The diversity of styles and variations of traditional batik in West Java is a source of strength that is not shared by other provinces. This research uses an empirical juridical approach method or a legislative approach to recognize the regulations that are already running in the community as well as descriptiveanalytical research specifications using primary data and secondary data. The superiority of West Java batik has been proven to color the treasury of Indonesian batik along with other traditional batiks. Government support, in this case, the Governor of West Java Province through regulations and Governor's Decree is expected to increase the productivity and glory of traditional West Java batik related to economic potential and as a form of support for the West Java Regional Government in the Regional Cultural Advancement program that has been stipulated in Law No. 5 of 2007. This research is expected to give
\end{abstract}


Serat Rupa Journal of Design, July 2020, Vol.4, No.2: 91-110

E-ISSN: 2477-586X, ISSN: 2338-3348 | https://doi.org/10.28932/srjd.v4i2.2558| Received: 12-06-2020, Accepted: 18-07-2020 Saftiyaningsih Ken Atik, Mochamad Djalu Djatmiko

Kajian Peraturan Gubernur Jawa Barat Tentang Penggunaan Batik Tradisional dan Upaya Pencapaian Indikasi Geografis

birth to the decision of the Governor of West Java regarding the use of traditional batik products (original batik) and a variety of typical decoration of West Java batik. West Java society in general.

Keywords: batik in West Java; geographical indication; strategic action

\section{PENDAHULUAN}

Di dalam naskah buhun Sunda "Siksa Kandang Ing Karesian" awal abad ke-16 yang berkenaan dengan artefak batik, terdapat fakta bahwa "disebut bermacam corak lukisan (tulis) antara lain: pupunjengan, hihinggulan, kekembangan, alas-alasan, urang-urangan, memetahan, sisirangan, taruk hata, kembang tarate, disebut juga beragam kain (boeh): kembang mu(n)cang, gagang senggang, anyam cayut, poleng re(ng)ganis, cecempaan, mangin haris, surat awi, parigi nyengsoh, hujan riris; yang menunjukkan bahwa pada masa naskah itu ditulis, orang Sunda telah mengenal berbagai corak kain (samping) dan batik. Walaupun tidak ada peninggalan dari Kerajaan Sunda, namun ditemukan beberapa helai kain berusia 200-300 tahun (Setiawan, 2010).

Berdasarkan wawancara yang dilakukan dengan para pengurus Yayasan Batik Jawa Barat (YBJB) disampaikan bahwa kerajinan batik tradisional kini sangat berkembang pesat di Provinsi Jawa Barat yang memiliki corak dan ciri khas motif yang unik. Sebelum berdirinya YBJB di tahun 2008, kondisi kerajinan batik Jawa Barat hanya terdapat di 8 kabupaten/kota. Setelah berdirinya YBJB hingga kini di Jawa Barat telah lahir pertumbuhan daerah-daerah baru penghasil kerajinan batik tradisional di 27 Kabupaten/kota, ini menunjukkan perkembangan batik yang sungguh menakjubkan dan menjadi prestasi bagi YBJB dan Pemda Jawa Barat. Di antara kota-kota di Jawa Barat yang menghasilkan batik tradisional adalah di pesisir sebelah utara Jawa Barat terdapat Batik Cirebon yang terkenal dengan teknik merawit, Indramayu terkenal dengan teknik complongan, Subang, Kerawang, dan Bekasi. Adapun yang terletak di tengah-tengah Jawa Barat terdapat Batik Kuningan, Sumedang, Bandung, Cimahi, Purwakarta. Di pesisir sebelah selatan terdapat Batik Banjar, Pangandaran, Tasikmalaya, Garut, dan Sukabumi. Di Jawa Barat kini hampir 27 Kabupaten Kota memiliki ragam hias batik tradisional dan corak yang berbeda-beda serta sangat variatif. Motif-motif batik Jawa Barat yang dimunculkan di daerah-daerah penghasil batik tradisional baru, ide dasarnya diolah dari hasil eksplorasi budaya lokal seperti: peninggalan artefak budaya seperti rumah adat, bangunan kuno bersejarah, kesenian daerah, hasil pertanian, benda bersejarah, dan tempat-tempat wisata yang dikenal menjadi ide dasar dalam penciptaan motif-motif baru batik tradisional di daerah-daerah tersebut. Selain Jawa Barat memiliki keunggulan pada ragam hias motif batiknya, terdapat pula kekhasan dan keunikan 
Serat Rupa Journal of Design, July 2020, Vol.4, No.2: 91-110

E-ISSN: 2477-586X, ISSN: 2338-3348 | https://doi.org/10.28932/srjd.v4i2.2558 | Received: 12-06-2020, Accepted: 18-07-2020 Saftiyaningsih Ken Atik, Mochamad Djalu Djatmiko

Kajian Peraturan Gubernur Jawa Barat Tentang Penggunaan Batik Tradisional dan Upaya Pencapaian Indikasi Geografis

teknik membatiknya yang dapat dijadikan sebagai kekuatan strategis pendaftaran Indikasi Geografis di Kemenkumham. Keunggulan teknik tersebut di antaranya teknik merawit yang dimiliki masyarakat pembatik tradisional di Kabupaten Cirebon dan teknik Complongan yang dimiliki pembatik Kabupaten Indramayu.

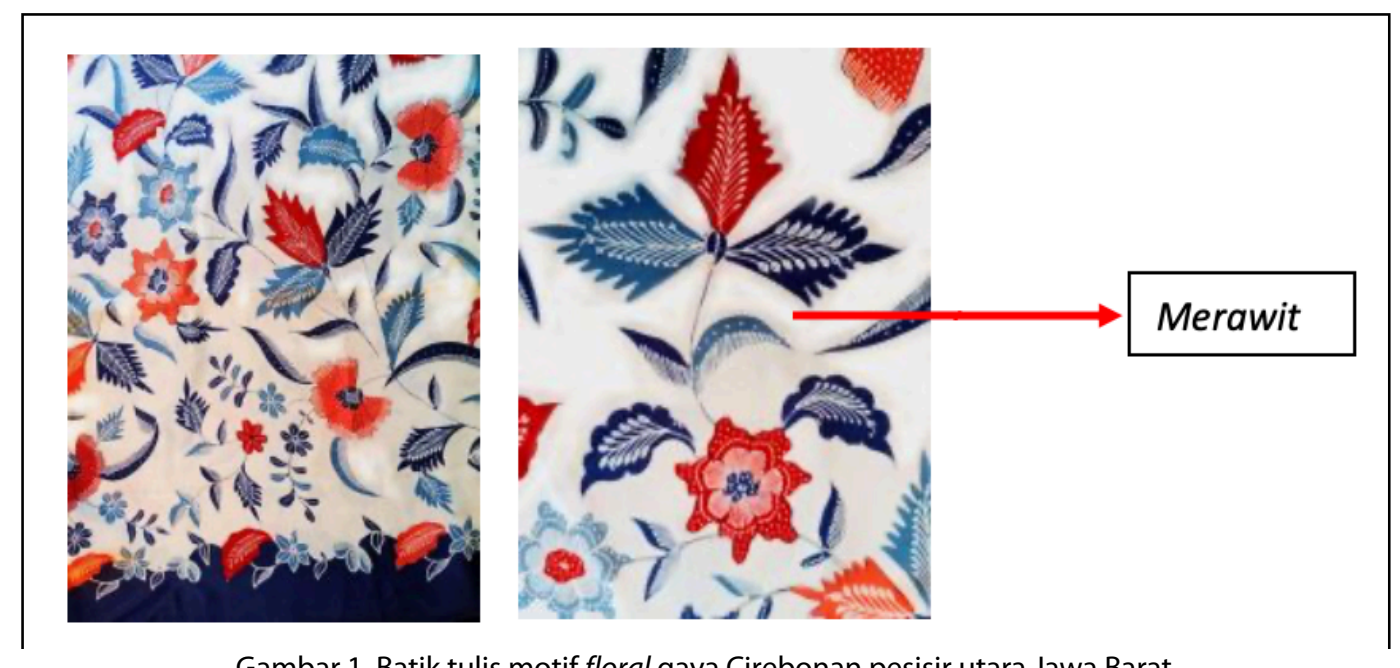

Gambar 1. Batik tulis motif floral gaya Cirebonan pesisir utara Jawa Barat dengan teknik merawit (garis halus tangkai),

sedang dalam proses pendaftaran indikasi geografis untuk batik Jawa Barat Sumber: foto \& batik koleksi Ken Atik, 2000

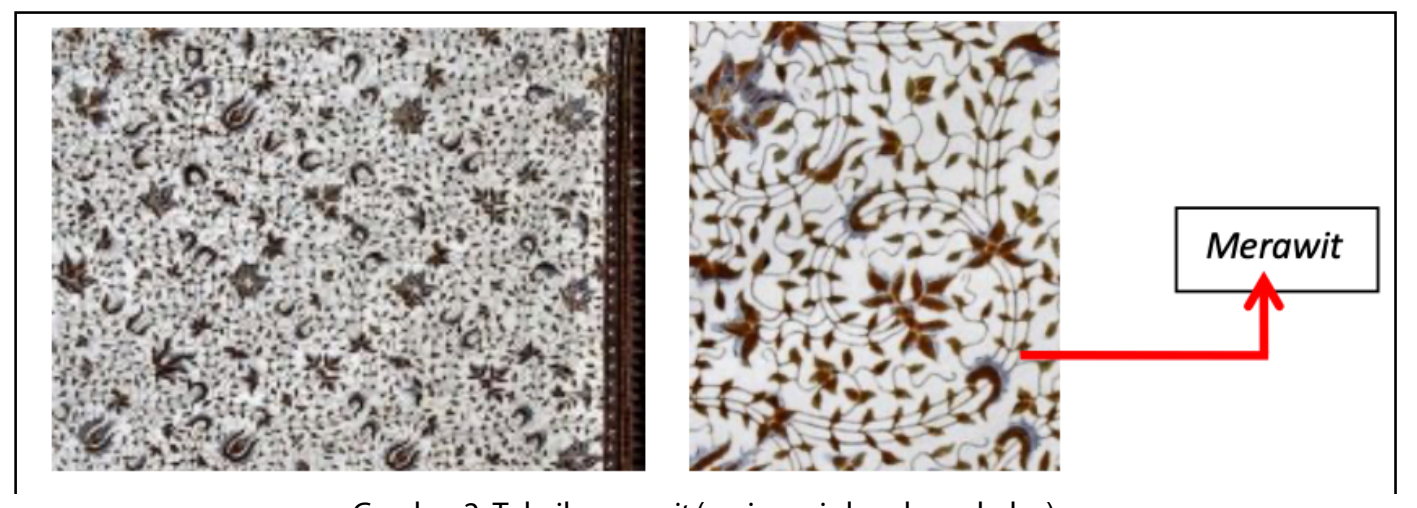

Gambar 2. Teknik merawit (garis-garis lengkung halus) pada batik tulis motif Tikel Balung Keraton Kasepuhan Cirebon, sedang dalam proses pendaftaran indikasi geografis untuk batik Jawa Barat Sumber: batik koleksi Yeyen Komar, 2014

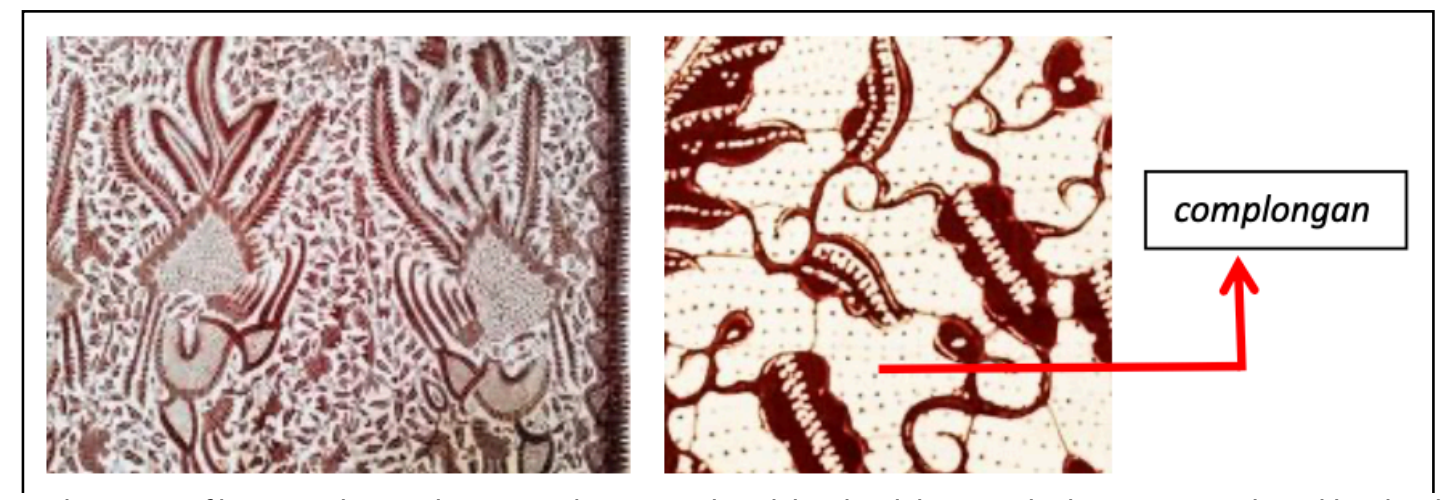

Gambar 3. Motif burung phoenix latar complongan (titik-titik kecil) salah satu teknik yang menjadi ciri khas batik tulis Indramayu pesisir utara Jawa Barat, sedang dalam proses pendaftaran 
Serat Rupa Journal of Design, July 2020, Vol.4, No.2: 91-110

E-ISSN: 2477-586X, ISSN: 2338-3348 | https://doi.org/10.28932/srjd.v4i2.2558| Received: 12-06-2020, Accepted: 18-07-2020 Saftiyaningsih Ken Atik, Mochamad Djalu Djatmiko

Kajian Peraturan Gubernur Jawa Barat Tentang Penggunaan Batik Tradisional dan Upaya Pencapaian Indikasi Geografis

indikasi geografis batik dari Jawa Barat

Sumber: foto \& batik koleksi Ken Atik, 2009

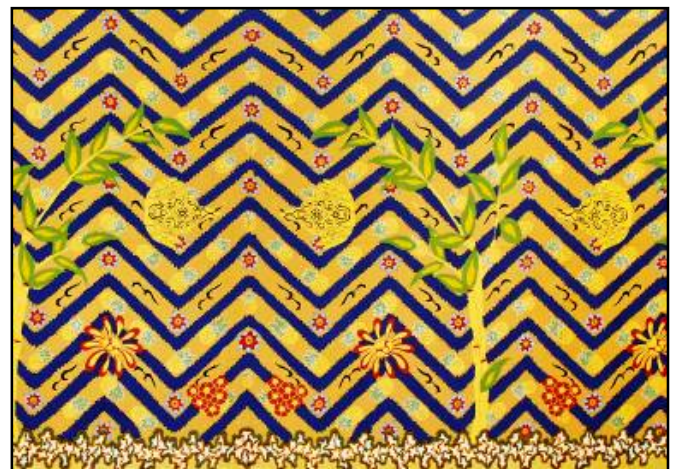

Gambar 4. Motif Subang Larang dari Kabupaten Subang termasuk batik pesisir utara Jawa Barat yang telah mengembangkan batik tulis dan cap sejak tahun 2012

Sumber: dokumen pribadi, 2013

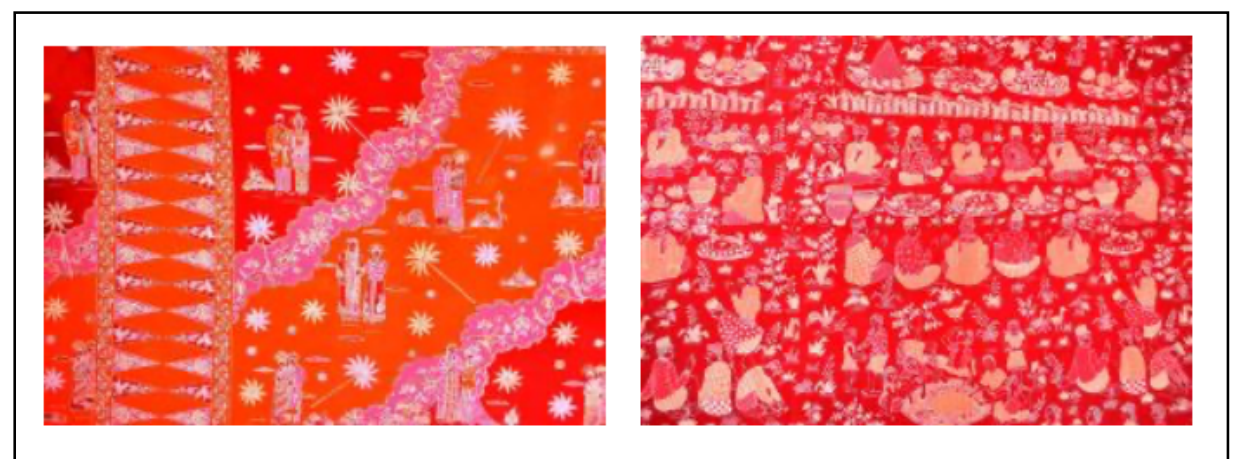

Gambar 5. Batik tulis Kota Bekasi motif Abang None (ki) dan Baritan (ka) yang telah dikembangkan sejak 2010 Sumber: dokumentasi YBJB, 2010

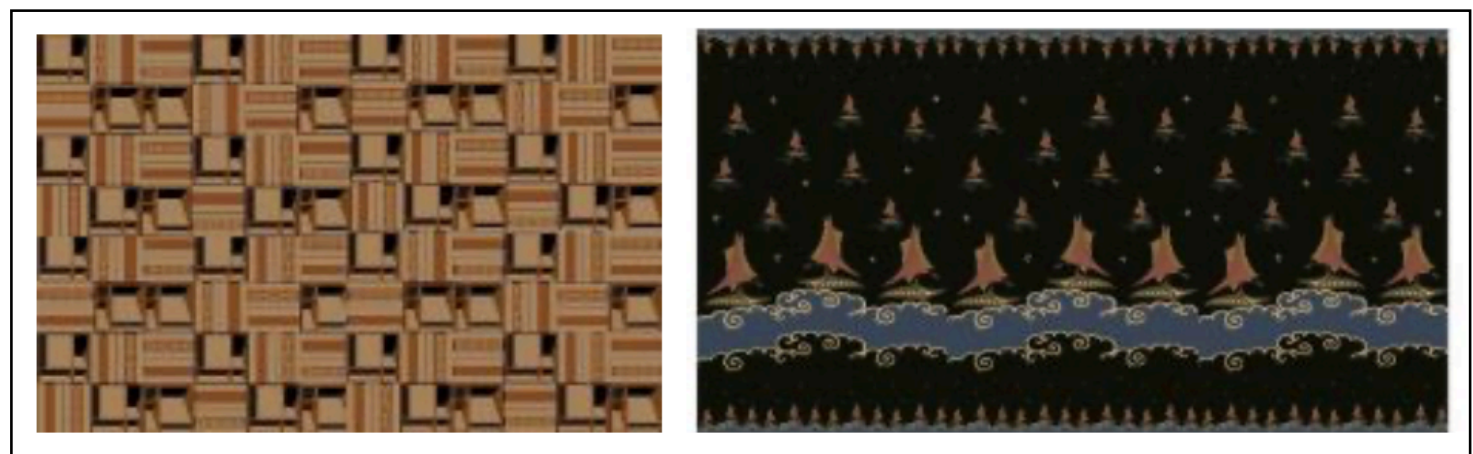

Gambar 6. Batik cap dan tulis motif Batagapit (ki), dan motif Jatiluhur (ka) hasil eksplorasi alam Kab. Purwakarta Sumber: dokumen pribadi, 2019

Daerah-daerah penghasil kerajinan batik tradisional di Jawa Barat mulai tumbuh pesat setelah tahun 2008. Hal tersebut sebagian besar tidak terlepas dari dukungan Yayasan Batik Jawa Barat (YBJB) yang didirikan pada tanggal 8 Agustus 2008. Yayasan Batik Jawa Barat merupakan wadah organisasi batik yang lahir dari semangat para pendirinya yang didukung oleh para pecinta, pemerhati, pelaku kerajinan batik dan sebagian akademisi yang bergerak di bidang kriya tekstil. Kiprah dan program YBJB didukung oleh dinas terkait di lingkungan pemerintahan Jawa Barat. Dalam kurun waktu 5 tahun hampir seluruh wilayah pembatikan 
Serat Rupa Journal of Design, July 2020, Vol.4, No.2: 91-110

E-ISSN: 2477-586X, ISSN: 2338-3348 | https://doi.org/10.28932/srjd.v4i2.2558 | Received: 12-06-2020, Accepted: 18-07-2020 Saftiyaningsih Ken Atik, Mochamad Djalu Djatmiko

Kajian Peraturan Gubernur Jawa Barat Tentang Penggunaan Batik Tradisional dan Upaya Pencapaian Indikasi Geografis

di Jawa Barat dapat dikunjungi oleh pendiri dan pengurus YBJB. Selanjutnya Sendy Yusuf, S.T., selaku Ketua YBJB bersama para pengurus semakin giat mengajak para ketua Dekranasda Kabupaten/Kota dan masyarakat untuk turut menumbuhkan kerajinan batik tradisional di wilayahnya masing-masing. Ajakan ini diperkuat ketika batik Indonesia ditetapkan sebagai Warisan Kemanusiaan untuk Budaya Lisan dan Nonbendawi (Masterpieces of the Oral and Intangible Heritage of Humanity) oleh UNESCO, pada 2 Oktober 2009, yang makin menguatkan semangat kemunculan batik kabupaten/kota di Jawa Barat.

Kegiatan YBJB tidak hanya melestarikan, mengembangkan, namun juga mengajarkan dan melahirkan para pembatik muda yang handal sebagai upaya regenerasi pembatik. YBJB juga telah menyusun dan menulis beberapa buku batik Jawa Barat dan buku saku batik Indonesia. Hal ini semakin memberi peluang batik tradisional Jawa Barat dikenal lebih luas baik di tingkat nasional maupun internasional, apalagi dengan kemunculan para tokoh batik tradisional dari wilayah Jawa Barat yang aktif dalam mengikuti berbagai pameran batik di dalam negeri maupun di luar negeri sebagai pembawa misi budaya batik Indonesia. Hal ini juga menjadi salah satu cara dan jalan agar batik tradisional Jawa Barat khususnya dapat terus berkembang, dan digunakan. Program kerja YBJB menurut ketua harian nya bapak Komarudin Kudiya, dan humas YBJB ibu Ledie Suwandhie dan bapak Djalu Djatmiko, bahwa program yang berkesinambungan selalu melibatkan para pembatik yang menjadi peluang bagi reputasi batik dalam pengurusan dokumen Indikasi Geografis Batik Jawa Barat. Indikasi Geografis adalah bagian dari kekayaan intelektual yang merupakan tanda yang menunjukkan daerah asal suatu barang dan/atau produk yang karena faktor lingkungan geografis mampu memberikan reputasi, kualitas, dan karakteristik tertentu pada barang dan/atau produk yang dihasilkan sehingga mampu meningkatkan nilai jual barang atau produk, demikian keterangan dari ketua harian YBJB.

Melalui YBJB dan para anggotanya yaitu para perajin batik di Jawa Barat, terus berupaya menjadi mitra penting untuk memenuhi kebutuhan batik tradisional sebagai seragam dan kebutuhan lainnya. Namun dari kondisi di lapangan sebagian besar di lingkungan Pemda Jabar masih banyak terdapat penggunaan seragam kain batik yang bukan terbuat dari proses batik tradisional, tapi batik tiruan (printing batik). Tentu saja hal ini sangat mengecewakan bagi para perajin batik tradisional dan menjadi salah satu penghambat yang berdampak pada penurunan jumlah produksi batik tradisional, mengurangi minat masyarakat pada kain batik tradisional, hingga bisa menjadi salah satu punahnya batik-batik 
Serat Rupa Journal of Design, July 2020, Vol.4, No.2: 91-110

E-ISSN: 2477-586X, ISSN: 2338-3348 | https://doi.org/10.28932/srjd.v4i2.2558 | Received: 12-06-2020, Accepted: 18-07-2020 Saftiyaningsih Ken Atik, Mochamad Djalu Djatmiko

Kajian Peraturan Gubernur Jawa Barat Tentang Penggunaan Batik Tradisional dan Upaya Pencapaian Indikasi Geografis

tradisional karena tidak adanya dukungan serius program pelestarian dan pemajuan kebudayaan daerah. Dengan demikian perlu dilakukan revisi keputusan Gubernur Jawa Barat guna menjamin dan melindungi secara hukum tentang penggunaan kain-kain batik tradisional (batik asli) yang juga akan berdampak strategis di saat dilakukan pendaftaran Indikasi Geografis untuk teknik pembuatan kerajinan batik Jawa Barat yang memiliki kekhasan dan keunikan produksinya.

Dalam penelitian ini akan dikaji bagaimana upaya pemerintah Provinsi Jawa Barat terhadap kerajinan batik tradisional yang merupakan bagian dari Pengetahuan Tradisional dan Ekspresi Budaya Tradisional dapat diimplementasikan dengan tepat sesuai perundangan sehingga menjadi tindakan strategis dalam pencapaian Indikasi Geografis Indonesia. Selain itu akan dikaji juga upaya pemerintah Provinsi Jawa Barat untuk melakukan revisi peraturan Keputusan Gubernur tentang pemakaian busana batik tradisional dan bukan tekstil bercorak batik (printing), sebagai implementasi nyata dalam melindungi, melestarikan serta mengembangkan reputasi kerajinan batik tradisional Jawa Barat. Dengan adanya perubahan Keputusan Gubernur tentang penggunaan kain batik tradisional (batik asli), diharapkan tidak terjadi penggunaan bahan seragam batik tiruan (printing) yang akan digunakan oleh pegawai Pemda Jabar.

\section{METODE PENELITIAN}

Kegiatan penelitian dilakukan dengan menggunakan metode pendekatan yuridis empiris atau pendekatan perundang-undangan (statute approach), yaitu hukum tidak hanya dipandang sebagai peraturan-peraturan atau kaidah-kaidah saja, tetapi juga meliputi penerapan dan bekerjanya hukum dalam masyarakat. Spesifikasi penelitian yaitu deskriptif analitis yakni penelitian ini dimaksudkan untuk memberikan gambaran secara rinci, sistematis dan menyeluruh mengenai segala sesuatu baik perundang-undangan maupun teori-teori hukum (Muhdlor, 2012). Adapun jenis dan sumber data dalam penelitian ini menggunakan data primer dan data sekunder. Penelitian hanya dilakukan terhadap mereka yang terpilih menjadi responden. Berdasarkan pertimbangan tersebut, maka yang menjadi sampel penelitian ini adalah H. M. Arifin Soendjaya, Kepala Dinas Perindustrian dan Perdagangan Provinsi Jawa Barat; Ir. Rahmat Taufiq Garsadi, M.Si., Kepala Biro Perekonomian Provinsi Jawa Barat, dan Katura, perajin batik tradisional Cirebon. 
Serat Rupa Journal of Design, July 2020, Vol.4, No.2: 91-110

E-ISSN: 2477-586X, ISSN: 2338-3348 | https://doi.org/10.28932/srjd.v4i2.2558 | Received: 12-06-2020, Accepted: 18-07-2020 Saftiyaningsih Ken Atik, Mochamad Djalu Djatmiko

Kajian Peraturan Gubernur Jawa Barat Tentang Penggunaan Batik Tradisional dan Upaya Pencapaian Indikasi Geografis

\section{PEMBAHASAN}

\section{Terminologi Batik dan Tekstil Bercorak Batik}

Tokoh batik nasional Iwan Tirta menyampaikan bahwa peradaban manusia selalu berkembang, dan satu di antara perkembangan yang dilakukan oleh sekelompok manusia adalah membuat bahan pakaian. Bahan yang digunakan untuk membuat pakaian tergantung dari teknologi dan bahan-bahan baku yang tersedia di lingkungan dan di masa tersebut. Selanjutnya, ketika kemampuan manusia berkembang dan mampu membuat benang, maka akhirnya kain-kain yang digunakan untuk bahan pakaian menggunakan benang yang dipintal (Kuhr, 2012). Dalam Kamus Besar Bahasa Indonesia, pengertian batik merupakan kain yang memiliki bentuk gambar yang prosesnya dibuat khusus dengan menggoreskan atau menerakan malam/lilin panas pada kain, kemudian diproses dengan cara tertentu, hal tersebut kemudian dikenal dengan istilah kain batik (Poerwadarminta, 2005).

Penjelasan di dalam buku batik Indonesia Indah jilid 8 (1997) menyebutkan asal-usul kata batik berasal dari Bahasa Jawa. Kebiasaan orang Jawa dalam menyebut kata "amba" yang berarti luas atau lebar. Sementara kata "tik" berasal dari kata dasar titik yang berupa bentuk ornamen dasar dari bidang garis. Bila digabungkan kedua kata tersebut menjadi istilah batik yang memiliki makna menghubungkan beberapa titik menjadi gambar tertentu pada kain yang luas atau lebar membentuk motif. Berdasarkan asal-usul kata tersebut, istilah "batik" kini menjelma sebagai warisan tradisi bangsa Indonesia yang tersebar di seluruh penjuru wilayah nusantara (Yan \& Sunarya, 2010). Penjelasan lain batik adalah melekatkan lilin pada kain putih sebelum kain tersebut diberi warna. Cara pelekatan lilin ini ada bermacammacam, yaitu menggunakan alat canting untuk menggoreskan lilin panas, canting cap atau kuas untuk mendapatkan gambaran motif batik (Samsi, 2011).

Balai Besar Kerajinan dan Batik (BBKB) Yogyakarta yang merupakan bagian dari Kementerian Perindustrian Republik Indonesia, telah membuat SNI untuk kategori batik, tiruan batik, dan paduan tiruan batik. Adapun istilah tiruan batik dan paduan tiruan batik dikelompokkan pada SNI 8184 -2015. Berdasarkan pengertian batik secara etimologi, pengertian batik terus berkembang dan secara umum bisa diartikan sebagai berikut: batik merupakan karya seni kolektif yang melibatkan banyak tenaga terampil yang mempergunakan teknik rintang celup pada material kain dengan menggunakan malam/lilin panas. Proses membatik pada umumnya diawali dengan tahapan: 
Serat Rupa Journal of Design, July 2020, Vol.4, No.2: 91-110

E-ISSN: 2477-586X, ISSN: 2338-3348 | https://doi.org/10.28932/srjd.v4i2.2558| Received: 12-06-2020, Accepted: 18-07-2020 Saftiyaningsih Ken Atik, Mochamad Djalu Djatmiko

Kajian Peraturan Gubernur Jawa Barat Tentang Penggunaan Batik Tradisional dan Upaya Pencapaian Indikasi Geografis

1. Menggambar motif batik dengan menggunakan pensil di atas kain atau media tertentu,

2. Meng-klowong (menggambar di atas kain) menggunakan malam/lilin panas,

3. Memberi isen-isen (isian berupa titik,garis, dan lain-lain),

4. Me-nembok (menutup dengan malam),

5. Mewarnai (celup atau kuas),

6. Me-lorod (menghilangkan malam/lilin dengan menggunakan air panas) (Kudiya et al., 2014).

Menurut SNI 0239 tahun 2014, batik adalah kerajinan tangan sebagai hasil pewarnaan secara perintangan menggunakan malam (lilin batik) panas sebagai perintang warna, dengan alat utama pelekat malam/lilin batik berupa canting tulis dan atau canting cap untuk membentuk motif tertentu yang memiliki makna. Sehingga dengan tegas dibedakan jika sekiranya ada motif batik pada media apapun dan prosesnya tidak menggunakan malam/lilin panas sebagai perintang warnanya, maka tidak boleh disebut dengan batik, tetapi disebut 'tiruan batik' atau tekstil bercorak batik (Kudiya, 2019). Sedangkan menurut SNI 8184 tahun 2015 tentang 'tiruan batik' dikatakan yaitu produk manual, semi masinal dan atau masinal yang dibuat menggunakan alat utama screen-rakel dan atau alat lain untuk melekatkan pewarna, bahan kimia cabut warna, dan atau malam/lilin dingin serta paduannya untuk membentuk motif. Adapun paduan tiruan batik adalah produk yang dikerjakan dengan teknik print malam dingin atau print warna, kemudian dikombinasi dengan teknik batik tulis atau batik cap (Balai Besar Kerajinan dan Batik, 2015) (Kudiya et al., 2014).

Dasar pengakuan diterimanya batik sebagai Warisan Budaya Takbenda milik Bangsa Indonesia tertulis di dalam dokumentasi nominasi inskripsi UNESCO sebagai berikut: Convention for the safeguarding of the intangible cultural heritage. Intergovernmental committee for the safeguarding of the intangible cultural heritage, Fourth session Abu Dhabi, United Arab Emirates, 28 September to 2 October 2009. Nomination for inscription on the Representative List in 2009 (Reference No. 00170). Pada bagian 1. Identification of the element, domain(s) represented by the element: Indonesian Batik represents the following domains: (e) Traditional Handcrafts;

"All the steps in the making of batik as included in this nomination file are carried out by hand. The tools used to make batik are also made by hand. Firstly, the cloth must be washed, soaked and beaten with a large mallet. A pattern is drawn and dots and lines of hot wax are then applied to one or both sides of the cloth using a pen-like instrument called canthing tulis (direngsi/ngrengrengi). Alternatively there is the process of applying the 
hot wax to the cloth using stamps called canthing cap made of copper The wax functions as a dye-resist. After this, the cloth is dipped in a dye bath containing the first colour. After the cloth is dry, the wax is removed by scraping or boiling the cloth (dilorod). This process is repeated as many times as the number of colours desired" (Steelyana, 2012).

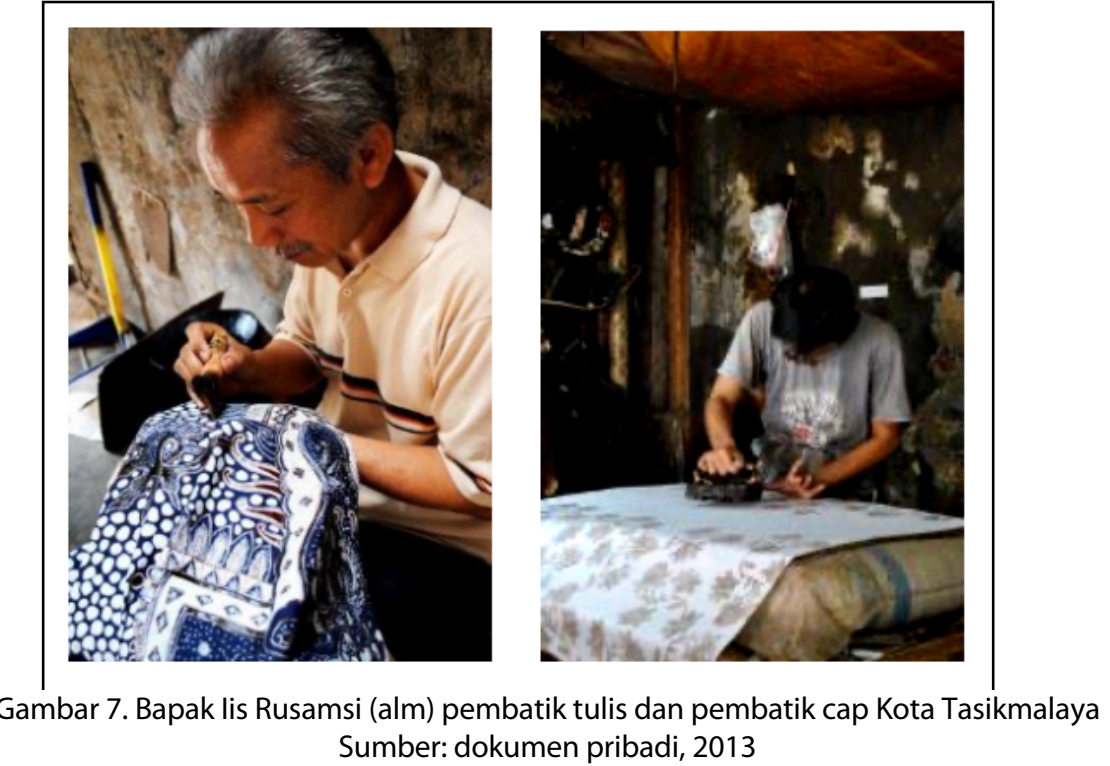

\section{Batik dalam Pandangan Hukum dan Perundang-undangan yang Ada di Indonesia}

Perlindungan terhadap batik tradisional yang termasuk dalam ranah kearifan lokal budaya Bangsa Indonesia telah tertuang dalam Undang-Undang Dasar 1945 tentang pengaturan mengenai kearifan lokal yang merupakan salah satu ciri dari hukum yang hidup dalam masyarakat. Hal tersebut dapat dipersamakan dengan hukum adat, dengan demikian pemerintah Indonesia harus mengakui dan mengatur lebih lanjut tentang kearifan lokal, hal tersebut dapat dilihat dalam Pasal 18 B ayat (2) dan juga ditegaskan pada Pasal 28 I ayat (3) Undang-Undang Dasar 1945 (Fajarini, 2014).

Dalam Undang-Undang Pengelolaan Lingkungan Hidup, kearifan lokal dapat dimaknai sebagai suatu nilai yang berlaku dalam kehidupan masyarakat untuk melindungi dan mengelola lingkungan hidup agar lestari, sehingga kearifan lokal ini dijadikan suatu asas atau dasar ketika melakukan perlindungan dan pengelolaan lingkungan hidup. Kearifan lokal termasuk di dalamnya Ekspresi Budaya Tradisional (EBT) meliputi semua warisan budaya tak benda yang dikembangkan oleh masyarakat lokal, secara kolektif atau individual dengan cara yang tidak sistemik dan disisipkan dalam tradisi budaya dan spiritual masyarakat (Roisah et al., 2014).

Kategori Warisan Budaya Tak Benda meliputi tradisi lisan, seni pertunjukan, praktik-praktik sosial, ritual, perayaan-perayaan, pengetahuan dan praktik mengenai alam dan semesta atau 
Serat Rupa Journal of Design, July 2020, Vol.4, No.2: 91-110

E-ISSN: 2477-586X, ISSN: 2338-3348 | https://doi.org/10.28932/srjd.v4i2.2558 | Received: 12-06-2020, Accepted: 18-07-2020 Saftiyaningsih Ken Atik, Mochamad Djalu Djatmiko

Kajian Peraturan Gubernur Jawa Barat Tentang Penggunaan Batik Tradisional dan Upaya Pencapaian Indikasi Geografis

pengetahuan dan keterampilan untuk menghasilkan kerajinan tradisional. Kerangka hukum EBT di Indonesia yang diimplementasikan sebagaimana terdapat dalam Undang-Undang Dasar RI Tahun 1945 (amandemen ke empat) Pasal 32 (1), Pasal 38 dan 39 tentang UndangUndang Hak Cipta No. 28 Tahun 2014, Undang-Undang Nomor 5 Tahun 2017 tentang Undang-Undang Pemajuan Kebudayaan yang lahir dalam rangka melindungi, memanfaatkan, dan mengembangkan kebudayaan Indonesia, Perpres RI No.78 Tahun 2007 tentang Konvensi Perlindungan Warisan Budaya Tak Benda, Permendikbud No.106 Tahun 2013 tentang Warisan Budaya Tak Benda Indonesia (Atsar, 2017).

Batik adalah salah satu bagian dari Budaya Tak Benda disebabkan batik memiliki semua dari pengertian Budaya Tak Benda. Dalam Permen Pendidikan dan Kebudayaan 106 tahun 2013, Bab1 Ketentuan Umum Pasal 1, menyebutkan:

a. Budaya Tak Benda adalah seluruh hasil perbuatan dan pemikiran yang terwujud dalam identitas, ideologi, mitologi, ungkapan-ungkapan konkret dalam bentuk suara, gerak, maupun gagasan yang termuat dalam benda, sistem perilaku, sistem kepercayaan, dan adat istiadat di Indonesia.

b. Warisan Budaya Tak Benda Indonesia adalah berbagai hasil praktik, perwujudan, ekspresi pengetahuan dan keterampilan, yang terkait dengan lingkup budaya, yang diwariskan dari generasi ke generasi secara terus menerus melalui pelestarian dan/atau penciptaan kembali serta merupakan hasil kebudayaan yang berwujud budaya tak benda setelah melalui proses penetapan Budaya Tak Benda.

Dari beberapa cuplikan tentang undang-undang terkait budaya tak benda, maka sudah selayaknya pemerintah daerah memiliki kewajiban untuk melakukan pelestarian, perlindungan, pengembangan dan pemanfaatan secara maksimal dan saling bersinergi dengan unsur-unsur pemerintahan terkait yang didukung dengan peraturan-peraturan pemerintah dan Peraturan Gubernur di wilayah masing-masing. Kebijakan yang berhubungan dengan Keputusan Gubernur Jawa Barat, seharusnya menjadi pijakan dalam langkah nyata dalam kehidupan sehari-hari bermasyarakat.

Beberapa ahli dan pakar kebijakan publik seperti Carl J. Federick sebagaimana dikutip Leo Agustino (2008:7) mendefinisikan kebijakan sebagai serangkaian tindakan/kegiatan yang diusulkan seseorang, kelompok atau pemerintah dalam suatu lingkungan tertentu dengan terdapat hambatan-hambatan (kesulitan-kesulitan) dan kesempatan-kesempatan terhadap 
Serat Rupa Journal of Design, July 2020, Vol.4, No.2: 91-110

E-ISSN: 2477-586X, ISSN: 2338-3348 | https://doi.org/10.28932/srjd.v4i2.2558 | Received: 12-06-2020, Accepted: 18-07-2020 Saftiyaningsih Ken Atik, Mochamad Djalu Djatmiko

Kajian Peraturan Gubernur Jawa Barat Tentang Penggunaan Batik Tradisional dan Upaya Pencapaian Indikasi Geografis

pelaksanaan usulan kebijaksanaan tersebut dalam rangka mencapai tujuan tertentu. Pendapat ini juga menunjukkan bahwa ide kebijakan melibatkan perilaku yang memiliki maksud dan tujuan merupakan bagian yang penting dari definisi kebijakan, karena bagaimanapun kebijakan harus menunjukkan apa yang sesungguhnya dikerjakan daripada apa yang diusulkan dalam beberapa kegiatan pada suatu masalah (Marta \& Agustino, 2019).

Seperti apa yang dikemukakan Solichin Abdul Wahab, bahwa istilah kebijakan sendiri masih terjadi silang pendapat dan merupakan ajang perdebatan para ahli. Maka untuk memahami istilah kebijakan, Solichin Abdul Wahab (2004: 40-50) memberikan beberapa pedoman sebagai berikut: Kebijakan harus dibedakan dari keputusan; Kebijakan sebenarnya tidak serta merta dapat dibedakan dari administrasi; Kebijakan mencakup perilaku dan harapanharapan; Kebijakan mencakup ketiadaan tindakan ataupun adanya tindakan; Kebijakan biasanya mempunyai hasil akhir yang akan dicapai; Setiap kebijakan memiliki tujuan atau sasaran tertentu baik eksplisit maupun implisit; Kebijakan muncul dari suatu proses yang berlangsung sepanjang waktu; Kebijakan meliputi hubungan-hubungan yang bersifat antar organisasi dan yang bersifat intra organisasi; Kebijakan publik meski tidak eksklusif menyangkut peran kunci lembaga-lembaga pemerintah; Kebijakan itu dirumuskan atau didefinisikan secara subjektif. Terlepas dari silang pendapat tentang pengertian kebijakan dan pengertiannya, namun yang pasti adalah Keputusan Gubernur yang telah dikaji dan ditetapkan berkaitan dengan penggunaan busana batik tradisional akan memberikan dampak positif di lapangan khususnya yang berkaitan dengan industri kerajinan batik tradisional Provinsi Jawa Barat itu sendiri.

Mengapa harus ditetapkan keputusan Gubernur Jawa Barat tentang penggunaan busana batik tradisional motif Jawa Barat? Hal ini dikaitkan dengan kebijakan pemerintah tentang perlunya upaya perlindungan ketahanan budaya, seperti yang telah diundang-undangkan oleh pemerintah melalui UU No. 5 tahun 2017 tentang Pemajuan Kebudayaan. Di dalam UUD 1945 Pasal 32 ayat 1 berbunyi: "Negara memajukan kebudayaan nasional Indonesia di tengah peradaban dunia dengan menjamin kebebasan masyarakat dalam memelihara dan mengembangkan nilai-nilai budayanya".

Batik di Jawa Barat merupakan aset daerah yang berpotensi bagi pengembangan dan peningkatan perekenomian masyarakat disebabkan pengerjaannya memberikan dampak multilayer yang cukup besar. Batik adalah usaha kerakyatan padat karya, dan merupakan 
Serat Rupa Journal of Design, July 2020, Vol.4, No.2: 91-110

E-ISSN: 2477-586X, ISSN: 2338-3348 | https://doi.org/10.28932/srjd.v4i2.2558 | Received: 12-06-2020, Accepted: 18-07-2020 Saftiyaningsih Ken Atik, Mochamad Djalu Djatmiko

Kajian Peraturan Gubernur Jawa Barat Tentang Penggunaan Batik Tradisional dan Upaya Pencapaian Indikasi Geografis

karya seni kolektif yang melibatkan banyak tenaga ahli. Sehingga sudah selayaknya bagi pemerintah Jawa Barat dapat melindunginya secara komprehensif dan dituangkan dalam bentuk kebijakan publik berupa Keputusan Gubernur tentang penggunaan busana batik tradisional motif khas asli Jawa Barat.

\section{Peraturan-Peraturan Gubernur di Indonesia yang Mendukung Penggunaan Pakaian Batik}

Terdapat beberapa Keputusan Gubernur dari beberapa provinsi di Indonesia yang pernah menerbitkan peraturan berkaitan dengan batik dan pemakaian kain batik. Namun, Keputusan Gubernur tersebut belum memberi dampak signifikan pada produk batik tradisional. Pertama, tentang Instruksi Gubernur Provinsi Daerah Khusus Ibukota Jakarta No. 2 Tahun 2010 Tentang Pemakaian Baju Batik. Dalam Instruksi Gubernur tersebut, tidak ada penjelasan mengenai penggunaan produk batik tradisional yaitu batik cap atau batik tulis. Seharusnya dalam instruksi dijelaskan dengan tegas dan terperinci mengenai penggunaan batik tradisional yang dibuat dengan teknik penggunaan lilin panas, baik batik cap maupun batik tulis. Dengan instruksi yang yang bersifat umum mengakibatkan realisasi dari Keputusan Gubernur tersebut adalah penggunaan kain bercorak batik alias printing.

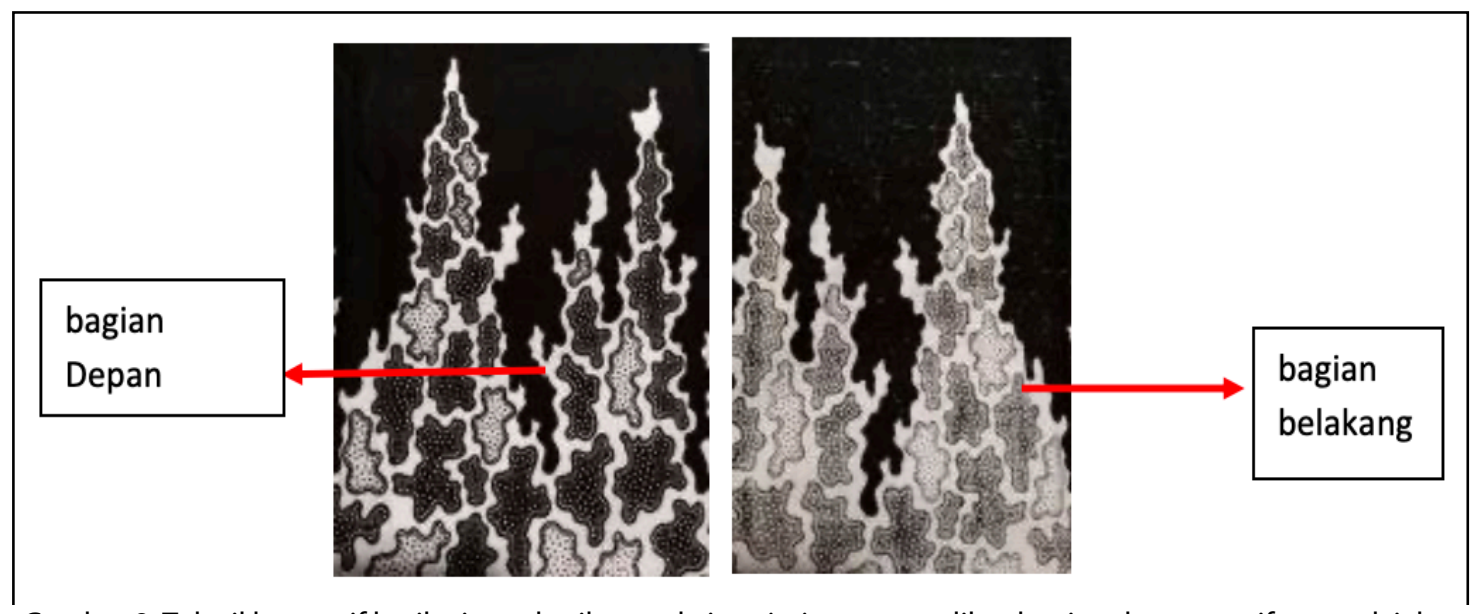

Gambar 8. Tekstil bermotif batik, tiruan batik, atau kain printing yang terlihat bagian depan motif nampak jelas namun pada bagian belakang gambar motif tidak jelas Sumber: dokumen pribadi, 2018

Kedua, tentang Peraturan Gubernur Jawa Barat Nomor 64 Tahun 2010 tentang Perubahan Atas Peraturan Gubernur Jawa Barat Nomor 9 Tahun 2008, tentang Pakaian Dinas di Lingkungan Pemerintah Provinsi Jawa Barat. Berlanjut dengan Peraturan Gubernur Jawa Barat Nomor 99 tahun 2015 Tentang Pakaian Dinas di lingkungan Pemerintah Daerah 
Serat Rupa Journal of Design, July 2020, Vol.4, No.2: 91-110

E-ISSN: 2477-586X, ISSN: 2338-3348 | https://doi.org/10.28932/srjd.v4i2.2558 | Received: 12-06-2020, Accepted: 18-07-2020 Saftiyaningsih Ken Atik, Mochamad Djalu Djatmiko

Kajian Peraturan Gubernur Jawa Barat Tentang Penggunaan Batik Tradisional dan Upaya Pencapaian Indikasi Geografis

Provinsi Jawa Barat. Pada Pasal 16 disebutkan (1) PDH Batik untuk pegawai pria menggunakan atribut dan kelengkapan sebagai berikut:

(a). Kemeja lengan panjang/pendek, motif batik; (b). Celana Panjang warna gelap; (c). Kaos kaki dan sepatu tertutup atau pantofel warna hitam; (d). Lencana Korpri, papan nama, dan tanda pengenal.

Model PDH Batik untuk pegawai pria sebagaimana dimaksud pada ayat (1), tercantum dalam lampiran Angka I, huruf A, nomor 13, sebagai bagian yang tidak terpisahkan dari Peraturan Gubernur ini. Pasal 17 menyebutkan (1) PDH Batik untuk pegawai wanita, menggunakan atribut dan kelengkapan sebagai berikut: a. Baju lengan panjang/pendek, motif batik; b. Rok $15 \mathrm{~cm}$ di bawah lutut atau rok panjang atau celanan panjang, tidak bermotif dan warna gelap atau disesuaikan; c. Sepatu tertutup atau pantofel warna hitam; dan d. Lencana Korpri, papan nama, dan tanda pengenal. (2) PDH Batik untuk pegawai wanita yang berjilbab atau wanita hamil menyesuaikan. (3) Model PDH Batik untuk pegawai wanita sebagaimana dimaksud pada ayat (1) tercantum pada Lampiran Angka I, huruf A, nomor 14, sebagai bagian yang tidak terpisahkan dari Peraturan Gubernur ini. Pasal 18 menyebutkan PDH Batik dapat digunakan pada kegiatan rapat/pertemuan yang dilaksanakan di luar kantor. Seperti halnya Keputusan Gubernur Jakarta, dalam peraturan Keputusan Gubernur Jawa Barat juga tidak menjelaskan dengan tegas, jelas dan terperinci tentang penggunaan batik yang dimaksud adalah penggunaan produk kain batik tradisional dengan motif yang diambil dari daerah dan wilayah masing-masing Kabupaten/ Kota di Jawa Barat. Sehingga yang terjadi adalah sebagian besar para pegawai sipil banyak yang menggunakan kain bercorak batik alias printing dan tidak memperhatikan motif batik berasal dari daerah Kabupaten/Kota di Jawa Barat atau daerah lain.

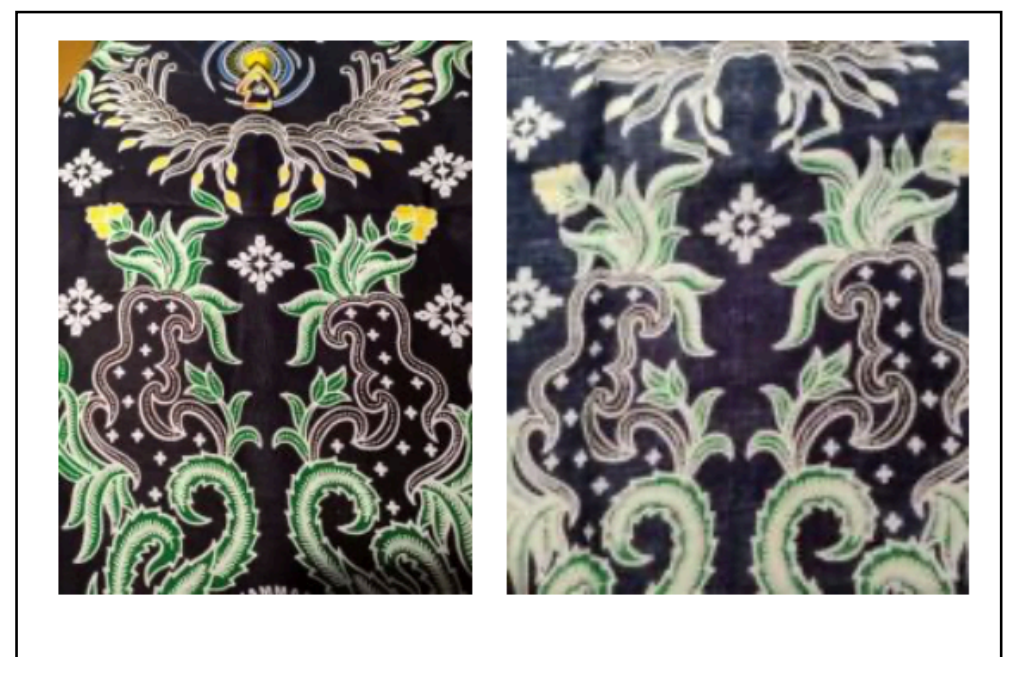


Serat Rupa Journal of Design, July 2020, Vol.4, No.2: 91-110

E-ISSN: 2477-586X, ISSN: 2338-3348 | https://doi.org/10.28932/srjd.v4i2.2558| Received: 12-06-2020, Accepted: 18-07-2020 Saftiyaningsih Ken Atik, Mochamad Djalu Djatmiko

Kajian Peraturan Gubernur Jawa Barat Tentang Penggunaan Batik Tradisional dan Upaya Pencapaian Indikasi Geografis

Gambar 9 . Tekstil bermotif batik, tiruan batik, atau kain printing umumnya tidak memiliki kualitas gambar motif sama antara bagian depan dan bagian belakang.

Sumber: dokumen pribadi, 2020

\section{Peraturan-Peraturan Bupati di Indonesia yang}

\section{Telah Mendukung Penggunaan Pakaian Batik}

Peraturan atau keputusan Bupati dari berbagai daerah telah mengusung penggunaan busana batik tradisional di lingkungan pemerintahnya masing-masing. Peraturan Pemerintah Kabupaten Bojonegoro Nomor 25 tahun 2013 tentang Busana khas Daerah Kabupaten Bojonegoro, Jawa Tengah dalam Bab IV Motif Batik Pasal 4 disampaikan bahwa: Busana khas daerah Kabupaten Bojonegoro menggunakan Batik Jonegoroan motif Sekar Jati dengan bentuk, warna dan corak sebagaimana tercantum dalam lampiran III yang tidak terpisahkan dari Peraturan Bupati ini.

Peraturan Bupati Bantul Daerah Istimewa Yogyakarta Nomor 35 tahun 2019 tentang Pakaian Dinas Aparatur Pemerintah di Lingkungan Pemerintahan Kabupaten Bantul. Disebutkan dalam paragraf 2 PDHJ pasal 3 disebutkan bahwa: PDH Batik 1. Batik motif Kawung Tirto Samudro warna cokelat/sogan; 2. Batik motif Bantul; 3. Celana panjang/rok warna selaras dengan warna batik; dan 4. Sepatu pantofel warna menyesuaikan. Peraturan Bupati Bandung Jawa Barat Nomor 33 Tahun 2016 Tentang Pakaian Dinas Pegawai Negeri Sipil di Lingkungan Pemerintah Kabupaten Bandung. Pada Bagian Keempat tentang Pakaian Dinas Harian Batik Corak Khas Kabupaten Bandung; Pasal 14 menyebutkan bahwa: PDH Batik PNS Pria, terdiri dari: (a). Kemeja lengan pendek/panjang dengan corak batik khas daerah; (b). Celana panjang warna menyesuaikan dengan motif batik; (c). Ikat pinggang kulit; (d). Lencana KORPRI, papan nama dan tanda pengenal. Adapun dalam Pasal 15 menyebutkan: (1) PDH batik corak khas Kabupaten Bandung PNS wanita, terdiri dari: (a). Baju lengan panjang, dengan corak batik khas daerah; (b). Rok panjang/celana panjang semata kaki dengan warna disesuaikan; (c). Sepatu pantofel warna hitam; dan (d). Lencana KORPRI, tanda jabatan, papan nama dan tanda pengenal; (2) PDH Batik PNS wanita hamil dapat disesuaikan. (3) PDH batik PNS wanita berjilbab dapat disesuaikan. Pada Peraturan Bupati Bandung ini juga tidak menyebutkan dengan tegas, jelas dan terperinci perihal istilah pakain motif batik. Tidak ada penjelasan dalam lampiran Peraturan Bupati mengenai kain corak batik khas daerah. Peraturan Bupati Pati Jawa Tengah Nomor 31 Tahun 2016 Tentang Perubahan Ketiga atas Peraturan Bupati Pati nomor 38 tahun 2012 Tentang Pakaian Dinas di Lingkungan Pemerintah Kabupaten Pati. Dalam Pasal 1 ayat 13 menyebutkan Pakaian Dinas Harian Batik/Tenun/Lurik Khas Kabupaten Pati yang selanjutnya disingkat PDH Batik/Tenun/Lurik 
Serat Rupa Journal of Design, July 2020, Vol.4, No.2: 91-110

E-ISSN: 2477-586X, ISSN: 2338-3348 | https://doi.org/10.28932/srjd.v4i2.2558 | Received: 12-06-2020, Accepted: 18-07-2020 Saftiyaningsih Ken Atik, Mochamad Djalu Djatmiko

Kajian Peraturan Gubernur Jawa Barat Tentang Penggunaan Batik Tradisional dan Upaya Pencapaian Indikasi Geografis

Khas Kabupaten Pati adalah pakaian dinas batik/tenun/lurik khas Kabupaten Pati yang dipakai pada hari dan acara tertentu. Dalam Lampiran menyebutkan bahwa PDH Batik Motif Mina Tani. Penggunaan Batik Motif Mina Tani sesuai dengan Peraturan Bupati Pati Nomor 38 Tahun 2013 tentang Batik Motif Mina Tani dan Penggunaan Pakaian Batik Motif Mina Tani. Dalam Peraturan Bupati ini juga tidak menyebutkan pengertian tentang batik secara khusus dan jelas (Perbup No.31, 2016).

\section{Peraturan Bupati atau Walikota yang Menyebutkan dengan Jelas Pengertian Batik}

Peraturan Walikota Balikpapan Provinsi Kalimantan Timur No. 15 Tahun 2016 Tentang Pemanfaatan Batik Khas daerah. Dalam peraturan ini berisi tentang penjabaran dari peraturan Walikota tersebut sebagai berikut: a. Batik adalah kain bergambar yang pembuatannya secara khusus dengan menuliskan atau menerakan malam pada kain tersebut kemudian diproses dengan cara tertentu; b. Batik Motif Khas Daerah adalah pakaian bermotif batik yang mempunyai ciri khusus dan menggambarkan kekhasan Balikpapan yang telah dipatenkan; c. Kekhasan adalah kekhususan yang tidak dimiliki oleh pihak lain; $\mathrm{d}$. Produk Lokal adalah produk yang dihasilkan oleh Industri Kecil dan Menengah di Kota Balikpapan; e. Pelaku Usaha adalah pelaku usaha batik motif khas daerah yang berdomisili di Kota Balikpapan; f. Pemangku Kepentingan adalah instansi pemerintah, pemerintah daerah, instansi swasta, BUMN, BUMD, perbankan, perhotelan, sekolah, dan perguruan tinggi ( http://dkumkmp.balikpapan.go.id).

Peraturan Bupati Rembang Nomor 29 Tahun 2017 tentang Pelestarian Batik Tulis Lasem. Peraturan Bupati ini sudah lebih spesifik. Dalam peraturan dituliskan dengan jelas pengertian dari batik. Dalam Bab I Ketentuan Umum Pasal 1 no. 5, Batik adalah kain bergambar yang pembuatannya secara khusus dengan menuliskan atau menerakan malam pada kain, kemudian pengolahannya diproses dengan cara tertentu, atau batik merupakan hasil penggambaran corak di atas kain dengan menggunakan canting sebagai alat gambar dan malam sebagai zat perintang dan pengerjaannya dengan menggunakan tangan, yang berarti bahwa teknik batik merupakan penerapan corak di atas kain melalui proses celup rintang warna dengan malam sebagai medium perintangnya; 6. Batik Tulis Lasem adalah batik tulis bermotif Lasem. Dalam Bab II Maksud dan Tujuan Pasal 2 berbunyi: Maksud Pelestarian Batik Tulis Lasem adalah untuk melindungi, melestarikan dan mengembangkan batik tulis Lasem sebagai karya cipta dan produk kebudayaan masyarakat daerah, serta sebagai penggerak ekonomi masyarakat di daerah. Pasal 3 berbunyi: Tujuan Pelestarian Batik 
Serat Rupa Journal of Design, July 2020, Vol.4, No.2: 91-110

E-ISSN: 2477-586X, ISSN: 2338-3348 | https://doi.org/10.28932/srjd.v4i2.2558| Received: 12-06-2020, Accepted: 18-07-2020 Saftiyaningsih Ken Atik, Mochamad Djalu Djatmiko

Kajian Peraturan Gubernur Jawa Barat Tentang Penggunaan Batik Tradisional dan Upaya Pencapaian Indikasi Geografis

Tulis Lasem adalah: a. Melestarikan batik tulis Lasem; b. Melestarikan praktik budaya membatik tradisional batik tulis Lasem sebagai kekayaan budaya masyarakat daerah; c. Meningkatkan taraf kehidupan para pembatik dan masyarakat (http://jdih.rembangkab.go.id/perbup-no-29-th-2017-perlindungan-batik-tulis-lasem/).

Peraturan Bupati Sleman Daerah Istimewa Yogyakarta Nomor 35 Tahun 2015 Tentang Tata Kelola Batik Sleman. Menyebutkan dalam Bab I Ketentuan Umum Pasal 1 pada nomor 7. Batik adalah Tekstil Indonesia yang motifnya dibuat dengan teknik pencelupan rintang menggunakan malam sebagai zat perintang warna yang dilekatkan menggunakan canting dan alat cap; 8. Batik Sleman adalah batik hasil kreasi pengrajin Batik Sleman yang memadupadankan visualisasi flora, fauna dan kondisi geografis yang ada di Wilayah Kabupaten Sleman. Dari sekian banyak peraturan yang telah dibuat dalam upaya penggunaan batik sebagai pakaian seragam, sebagian besar tidak secara tegas dan terperinci menjelaskan jenis batik yang diinstruksikan. Antara peraturan dan pelaksanaan tidak ada kesesuaian. Sementara peraturan yang sudah jelas menyebutkan penggunaan batik tradisional pun pada kenyataannya tidak secara konsisten dijalankan.

\section{Nilai Strategis yang Diharapkan dari Peraturan Pemerintah tentang Batik}

Strategi merupakan kegiataan perencanaan dalam mencapai tujuan berdasarkan metode tertentu, yang didasarkan pada analisis yang terintegrasi dan holistik. Strategi disusun dari unsur yang ada dalam organisasi dalam presfektif jangka panjang, kemudian dirumuskan untuk merealisasikan visi dan misi korporasi untuk mencapai kinerja yang memuaskan dan sesuai terget (eprints.walisongo.ac.id).

Nilai-nilai strategis terhadap batik Jawa Barat adalah dengan dilahirkannya peraturan pemerintah baik dari pemerintah kabupaten/pemerintah kota, terlebih pada peraturan gubernur di tingkat provinsi yang harus memiliki konsistensi antara peraturan dan pelaksanaanya agar sejalan dengan perlindungan dan pengembangan batik tradisional di daerah-daerah dengan Undang-undang no. 5 tahun 2017 tentang Pemajuan Kebudayaan, Undang-undang nomor 28 tahun 2014 tentang Hak Cipta Pengetahuan Tradisional dan Ekspresi Budaya Tradisional (PTEBT), dan sejalan dengan Peraturan Menteri Hukum dan HAM nomor 12 tahun 2019 tentang Indikasi Geografis dan Keputusan Menteri Dalam Negeri nomor 53 tahun 209 tentang Pakaian Dinas PNS. Oleh karenanya penggunaan batik yang diproses dengan menggunakan cara batik tulis maupun cap menjadi keputusan strategis 
Serat Rupa Journal of Design, July 2020, Vol.4, No.2: 91-110

E-ISSN: 2477-586X, ISSN: 2338-3348 | https://doi.org/10.28932/srjd.v4i2.2558 | Received: 12-06-2020, Accepted: 18-07-2020 Saftiyaningsih Ken Atik, Mochamad Djalu Djatmiko

Kajian Peraturan Gubernur Jawa Barat Tentang Penggunaan Batik Tradisional dan Upaya Pencapaian Indikasi Geografis

yang berdampak secara kultural untuk peningkatan pengetahuan, upaya perlindungan, pengembangan aset budaya daerah yang memiliki reputasi sebagai produk berkualitas dan bernilai ekonomi.

Nilai-nilai strategis yang akan didapatkan dari Peraturan Gubernur di antaranya dapat terwujudnya implementasi pemajuan kebudayaan provinsi Jawa Barat:

1. Perlindungan adalah upaya menjaga keberlanjutan kebudayaan tradisi batik tradisional Jawa Barat yang kini sudah terdapat di 27 Kabupaten/Kota dengan cara inventarisasi, pengamanan, pemeliharaan, penyelamatan, penggunaan, dan publikasi.

2. Pengembangan adalah upaya menghidupkan ekosistem kebudayaan khususnya tradisi batik tradisional serta meningkatkan, memperkaya, dan menyebarluaskan kebudayaan batik tradisional Jawa Barat ke tingkat nasional dan internasional.

3. Pemanfaatan adalah upaya pendayagunaan objek pemajuan kebudayaan untuk menguatkan ideologi, politik, ekonomi, sosial, budaya, pertahanan, ketahanan sandang, dan keamanan dalam mewujudkan tujuan nasional.

4. Pembinaan adalah upaya pemberdayaan sumber daya manusia kebudayaan, lembaga kebudayaan, dan pranata kebudayaan dalam meningkatkan dan memperluas peran aktif dan inisiatif masyarakat berbudaya.

\section{PENUTUP}

Dari kajian mengenai posisi batik dalam perundangan, peraturan, kebijakan pemerintah provinsi, daerah kabupaten/kota terdapat beberapa simpulan:

a. Berdasarkan data di lapangan, di beberapa provinsi ditemukan Peraturan Gubernur (Pergub) Peraturan Bupati (Perbup), Peraturan Walikota (Perwal) yang telah menyebutkan berkaitan dengan penggunaan motif batik khas daerah masing-masing. Namun dalam peraturannya tidak menjelaskan secara jelas, tegas dan terperinci tentang pengertian batik tradisional sesuai dengan SNI Batik dari Kementerian Perindustrian melalui Balai Besar Kerajinan dan Batik Yogyakarta. Peraturan yang tidak jelas dan tegas menyebabkan kondisi di lapangan tidak selaras dengan apa yang menjadi harapan para UKM batik dan pemerhati budaya batik.

b. Peraturan Gubernur Jawa Barat dalam hal penggunaan kain batik sebagai Pakaian Dinas ASN di daerahnya masing-masing sudah sesuai dan sejalan dengan UU Republik Indonesia Nomor 5 tahun 2017 tentang Pemajuan Kebudayaan, namun dalam 
Serat Rupa Journal of Design, July 2020, Vol.4, No.2: 91-110

E-ISSN: 2477-586X, ISSN: 2338-3348 | https://doi.org/10.28932/srjd.v4i2.2558 | Received: 12-06-2020, Accepted: 18-07-2020 Saftiyaningsih Ken Atik, Mochamad Djalu Djatmiko

Kajian Peraturan Gubernur Jawa Barat Tentang Penggunaan Batik Tradisional dan Upaya Pencapaian Indikasi Geografis

implementasinya belum sepenuhnya terwujud. Hal ini terjadi karena peraturan yang masih dirasakan belum secara tegas, dan terperinci menjelaskan tentang batik yang harus digunakan. Peraturan pejabat pemerintah yang telah sesuai dengan kriteria batik tradisional pun harus mendapat pengawalan, dan pengawasan dalam implementasinya, agar setiap peraturan perundangan antara yang tertulis dan terlaksana tetap konsisten, tepat sasaran dan tepat guna.

c. Membangun kesadaran, membangun minat, menumbuhkan rasa setia, dan menggalakkan penggunaan, menjadi beberapa langkah dalam mendukung pelestarian batik yang memiliki dampak ekonomi yang signifikan bagi kesejahteraan UKM batik di berbagai daerah kabupaten dan kota di Jawa Barat. Sebab jika tidak ditumbuhkan kesadaran terus-menerus akan pentingnya pengetahuan dan penggunaan batik tradisional, maka batik bisa jadi lambat laun akan menghilang. Karena itu peraturan dan perundangan yang konsisten dan tegas juga menjadi bagian dari proses untuk pencapaian Indikasi Geografis (IG) Batik Jawa Barat.

\section{Saran}

1. Dibutuhkan adanya Keputusan Gubernur Jawa Barat yang baru, untuk menggantikan Peraturan Gubernur Jawa Barat Nomor 99 tahun 2015 Tentang Pakaian Dinas di Lingkungan Pemerintah Daerah Provinsi Jawa Barat. Penggantian keputusan yang dimaksud dengan menambahkan pada Peraturan Gubernur Jawa Barat tahun 2020 Tentang Pakaian Dinas di lingkungan Pemerintah Daerah Provinsi Jawa Barat dengan perincian yang jelas dan tegas tentang penggunaan batik tradisional; batik tradisional teknik cap atau teknik batik tulis menggunakan motif khas dari Jawa Barat. Keterangan perihal tentang batik tradisional bisa dijelaskan dalam lampiran keputusan gubernur yang tidak terpisahkan.

2. Mengingat pentingnya nilai-nilai strategis yang dimiliki oleh batik tradisional Jawa Barat, maka harus segera dilakukan identifikasi seluruh potensi kerajinan batik tradisional yang memiliki keunggulan, memiliki karakteristik, memiliki reputasi dan wilayah strategis untuk didaftarkan Indikasi Geografisnya (IG). Hal ini sebagai upaya untuk melestarikan, sosialisasi, edukasi, terkait pengetahuan tradisional, dan kepedulian pada kekayaan budaya yang bernilai, sehingga akan berdampak pada meningkatnya wawasan, pengetahuan dan nilai ekonomi bagi batik tradisional Jawa Barat.

\section{DAFTAR PUSTAKA}


Serat Rupa Journal of Design, July 2020, Vol.4, No.2: 91-110

E-ISSN: 2477-586X, ISSN: 2338-3348 | https://doi.org/10.28932/srjd.v4i2.2558 | Received: 12-06-2020, Accepted: 18-07-2020 Saftiyaningsih Ken Atik, Mochamad Djalu Djatmiko

Kajian Peraturan Gubernur Jawa Barat Tentang Penggunaan Batik Tradisional dan Upaya Pencapaian Indikasi Geografis

Atsar, A (2017). Perlindungan Hukum terhadap pengetahuan dan ekspresi budaya tradisional untuk peningkatan kesejahteraan masyarakat ditinjau dari undang-undang no.5 tahun 2017 tentang pemajuan kebudayaan dan undang-undang no.28 tahun 2014 tentang hak cipta. Law reform. http://doi.org/10.14710/Ir.v13i2.16162.

Fajarini, U.(2014). Peranan kearifan likal dalam pendidikan karakter sosio didaktika : social science education journal. http://doi.org/10.15408/sd.v1i2.1225

Kudiya, K., Sabana, S.,Sachari, A. (2014). Revitalisasi ragam hias batik keraton cirebon dalam desain baru kreatif. Panggung. http://doi.org/10.26742/panggung.v24i2.116

Kuhr, D.-R. G. (2012). Iwan Tirta (1960-2000) - The commodification of Batik: Brokering past as present \& the re-imagination of "Indonesian personality." ProQuest Dissertations and Theses. https://doi.org/10.1017/CBO9781107415324.004

Marta, A. \& Agustino, L. (2019). Analisis policy networks : utilitas dan limitasi. Jurnal agregasi : aksi reformasi government dalam demokrasi. http://doi.org/10.34010/agregasi.v7i1.1542

Muhdlor, A.Z. (2012). Perkembangan metodologi penelitian hukum. Jurnal hukum dan peradilan. http://doi.org/10.25216/jhp.1.2.2012.189-206

Roisah, K.,dkk.(2014). Perlindungan ekspresi budaya tradisional dalam sistem hukum kekayaan intelektual. Perlindungan ekdspresi budaya tradisional dalam sisten hukum kekayaan intelektual, 43(3), 372-379. http://doi.org/10.14710/mmh.43.3.2014.372-379

Poerwadarminta. (2005). Kamus Umum Bahasa Indonesia. Jakarta: Balai Pustaka. Muhibbin Syah. https://doi.org/10.1016/j.bbapap.2013.06.007

Samsi, Sri Soedewi. (2011), Teknik dan ragam hias batik Yogya dan Solo, Jakarta, Yayasan Titian Masa Depan.

Setiawan, I.(2010). Batik Garut: studi tentang sistem produksi dan pemasaran. Patanjala:jurnal penelitian sejarah dan budaya. http://doi.org/10.30959/patanjala.v.2i3.236

Steelyana, E.(2012). Batik a beautful cultural heritage that preserve culture and support economic development in indonesia. Jakarta, Binus business review.

Wahab, Solichin Abdul. (2004). Analisis kebijakan: dari formulasi ke implementasi kebijaksanaan Negara, Jakarta, Bumi aksara

Yan, O., \& Sunarya, Y. (2010). Batik Priangan modern dalam konstelasi estetik dan identitas. Terbitan Asosiasi Pendidik Seni Indonesia.

Sumber online

http://eprints.walisongo.ac.id/7292/3/BAB\%20II.pdf 
Serat Rupa Journal of Design, July 2020, Vol.4, No.2: 91-110

E-ISSN: 2477-586X, ISSN: 2338-3348 | https://doi.org/10.28932/srjd.v4i2.2558 | Received: 12-06-2020, Accepted: 18-07-2020 Saftiyaningsih Ken Atik, Mochamad Djalu Djatmiko

Kajian Peraturan Gubernur Jawa Barat Tentang Penggunaan Batik Tradisional dan Upaya Pencapaian Indikasi Geografis

http://jdih.rembangkab.go.id/perbup-no-29-th-2017-perlindungan-batik-tulis-lasem/

http://dkumkmp.balikpapan.go.id/detail/pengumuman/41/peraturan-walikota

menggunakan-batik-motif-khas-Salinan Peraturan Bupati Bojonegoro nomor 25

tahun 2013 tentang Busana Khas Daerah Kabupaten Bojonegopro + Lampiran

Perbup Bojonegoro nomor 25 tahun 2013

https://kec-bantul.bantulkab.go.id/filestorage/berkas/2019/05/peraturan-bupati-2019-

35.pdf

https://jdih.kebumenkab.go.id/index.php/produkhukum/download/1487 